\title{
Chromosome Complement of Kinugasa japonica with Special Reference to Its Origin and Behavior
}

By

Tutomu Haga

Faculty of Science, Hokkaido Imperial University, Sapporo

Recized January 15, 1937

Kinugasa japonica TATEWAKI et SuTô ${ }^{1)}(2 \mathrm{n}=40)$ is an octoploid plant of the tribe Parideae which comprises 2n-, 3n-, 4n- and $8 n-$ plants with the morphologically closely similar basic complement consisting of 5 chromosomes A, B, C, D and E (HAGA 1934). In his previous paper the writer determined the somatic and gametic chromosome number in root-tip cells, PMCs and pollen grains respectively, but at that time the finer morphology of the complement was not decided as to the trabants. By the present study pending points were settled, shedding further light upon the problem discussed in the previous paper.

\section{Morphology of the Chromosome Complement}

The gametic complement of this plant is composed of $4(\mathrm{~A}+\mathrm{B}+$ $\mathrm{C}+\mathrm{D}+\mathrm{E})=20$ chromosomes, of which one $\mathrm{C}$ is satellited with a
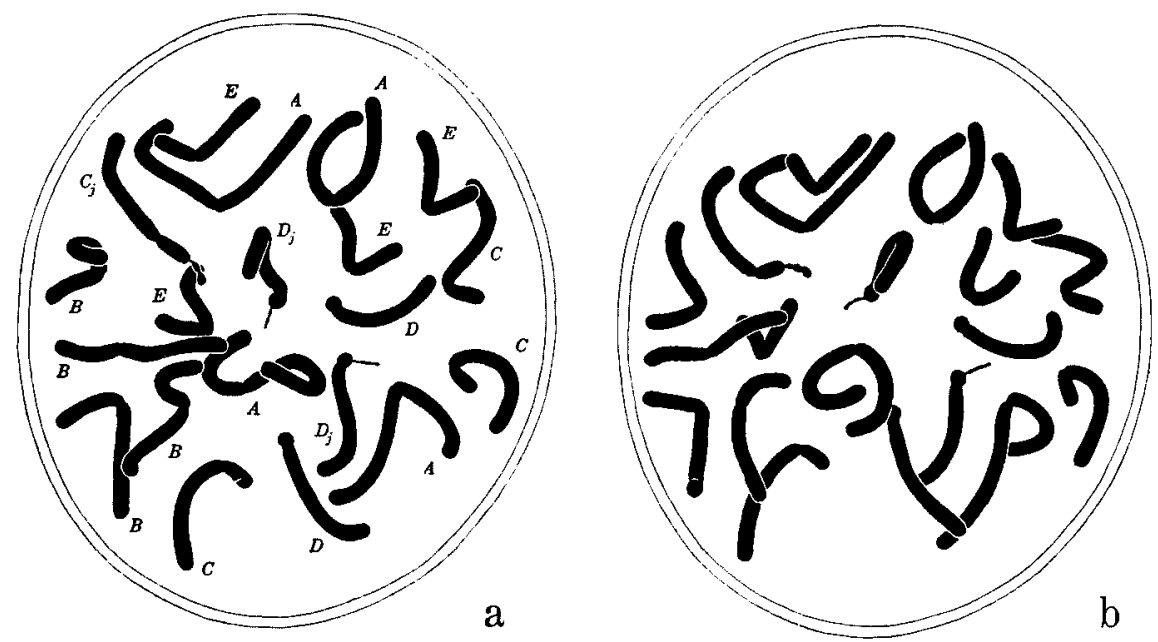

Text=fig. 1. An early anaphase polar view of the primary pollen-nucleus division. The sister groups are shown separately in two optical planes a and b. Acetocarmine preparation. $\times 875$.

1) Synonymous with Paris japonica Franch. (cf. Tatewaki and Surô 1935). 
large beaded trabant and two D's with seta-like one, being designated as $C_{j}$ and $D_{j}$ respectively. Further distinctions were noted also between the 4 members of $\mathrm{B}$ and $\mathrm{E}$ chromosomes (Text-fig. 1). The same constitution of the complement was ascertained in some fifty pollen grains from different individuals. Thus the above described is considered in all probability to represent the normal complement of this plant.

The above evidences in chromosome morphology strongly suggest the 4-genomatic origin of the complement as shown in the adjoin-

$$
\begin{gathered}
\mathrm{A}_{1}+\mathrm{B}_{1}+\mathrm{C}_{1}+\mathrm{D}_{1}+\mathrm{E}_{1} \\
\mathrm{~A}_{2}+\mathrm{B}_{2}+\mathrm{C}_{2}+\mathrm{D}_{2}+\mathrm{E}_{2} \\
\mathrm{~A}_{3}+\mathrm{B}_{3}+\mathrm{C}_{3}+\mathrm{D}_{3}+\mathrm{E}_{3} \\
\mathrm{~A}_{4}+\mathrm{B}_{4}+\mathrm{C}_{4}+\mathrm{D}_{4}+\mathrm{E}_{4} \\
(+ \\
4 \text { (A+B+C+D+E)= } \\
20 \text { chromosomes. }
\end{gathered}
$$

Scheme 1. A schematic formulation of the gametic complement of Kinugasa japonica. Chromosomes composing 4 different genoms are shown with the sufixes 1-4. ing scheme (Scheme 1). Further supports for this hypothesis are offered by the failure of multivalent pairing at the meiosis and the geographical peculialities of the present species. Accordingly the plant may have arisen through phylogenetical hybridisation as in polyploids of the related genus Trillium (cf. HAGA 1937 a). On the basis of crossability within as well as between all genera of the Parideae, i.e. Trillium, Paris and Kinugasa, the ancestral plants are considered as having been contributed probably from Trillium as well as from Paris. But which chromosome is Trillium- and which Parisorigin is not deducible without any genomanalytical investigation. For, as is demonstrated in Paris hexaphylla, profound structural alteration in the chromosome must have occurred before and after the appearance of this octoploid species (cf. HAGA $1927 \mathrm{~b}$ ).

\section{Meiosis}

Normal. At first metaphases in PMCs each 20 bivalents are formed, those resulting from the pairing in $4\left(\mathrm{~A}_{\mathrm{II}}+\mathrm{B}_{\mathrm{II}}+\mathrm{C}_{\mathrm{II}}+\mathrm{D}_{\mathrm{II}}+\right.$ $\mathrm{E}_{\text {II }}$ ) (Pl. 12, Fig. 1). In no case was multivalent pairing observed. This and the morphological quadruplicity are good enough evidences for the above formulation of the genom composition of this plant. The processes from the first anaphase up to the post-meiotic division are quite regular (Text-fig. 1, Pl. 12, Figs. 1-2).

Irregular. This plant is a sub-alpine habitant, performing its meiosis and past-meiotic division very probably under the snow in the habitat. The present observation was carried with materials transplanted from its native place in Mt. Gassan (Yamagata prefecture, $1500 \mathrm{~m}$. high) to Sapporo. In this material meiosis occurred in 
middle October and post-meiotic division in December and the next January.

The meioses were irregular partially to almost totally according to the different flowers, resulting in a few or no good pollen grains (Pl. 13, Fig. 9). Frequency of

the irregular division in a rather normal flower is shown in Table 1.

In view of the following two facts it seems most probable that these irregularities are due to neither genetical nor structural hybridity, but to the environmental changes mostly in temperature and in nutrition: (1) in its natural

Table 1. Frequency of the irregular meiosis in PMCs from a rather normal flower.

\begin{tabular}{l|r|c}
\hline \multicolumn{1}{c|}{ Division } & PMCs & $\begin{array}{c}\text { Occur- } \\
\text { rence in \% }\end{array}$ \\
\hline normal & 5155 & 78.7 \\
with 2-4 univalents & 284 & 4.3 \\
with fragmentation & 894 & 13.7 \\
with combined irreg. $)$ & 218 & 3.3 \\
\hline \multicolumn{1}{c|}{ Sum } & 6551 & 100.0
\end{tabular}

1) Here included tertiary splitting, regression and the extreme irregularities composed of several different irregularities. habitat the good pollen formation is quite normal and (2) in diploids of the related species of Paris and Trillium similar irregularities occur, though less frequently, under certain circumstances (Pl. 13, Figs. 11-13).

Observed irregularities consisted of non-pairing at metaphase, probably, desynapsis of chromosomes (Pl. 12, Figs. 3-4), fragmentation and fusion (Pl. 12, Figs. 5-6; Pl. 13, Figs. 7-8), regression of the first division, partial and total splitting into ultimate thread (Pl. 12, Fig. 5; Pl. 13, Fig. 10), disturbance or incompleteness of the spindle bipolarity (Pl. 12, Figs. 5-6; Pl. 13, Figs. 7-10) and their mixed occurrence in a PMC (Pl. 12, Figs. 5-6). Non-pairing or univalent formation at metaphase is a well-known phenomenon which is caused by change in temperature (e.g. TAKAGI 1928); its occurrence in only one or two component chromosomes of the complement is explicable by the partial effects of the affection. The feature of fragmentation-fusion is quite identical with that induced by X-radiation, so the mechanical interpretation of the phenomenon is omitted here (cf. MATSUURA and HaGa 1937). In a majority of cases fragmentation-fusion was accompanied by other irregularities such as desynapsis, tertiary splitting, etc. (Pl. 12, Figs. 5-6; Pl. 13, Fig. 7). In consequence of such meiotic divisions very irregular pollen-tetrads are formed (Pl. 13, Fig. 9).

Special interest is called to the occurrence of the tertiary splitting (division into the untimate threads), which happens partially as well as totally in the complement (Pl. 12, Fig. 5; Pl. 13, Fig. 10). The thickness of the split thread was half a diameter of the half univalents. This observation would contribute to the knowledge as to the finer structure of the chromosomes (cf. NEREL 1936). 
Spindle polarity is disturbedly weakened or nullified in the cases when severe fragmentation takes place, consequently forming two or more unequal irregularly distributed chromosome masses or numerous fragments scattered in the whole space (Pl. 12, Figs. 5-6; Pl. 13, Figs. 7-10).

\section{Geographical}

Kinugasa japonica shows a characteristic distribution, growing only in the ecologically equivalent sub-alpine regions in the mountains located in north to middle part of the main island of Japan (between the latitudes $36^{\circ}-39^{\circ}$ north) ${ }^{1)}$. In contrast to it distributions of the other plants of the Parideae, i.e., Paris hexaphylla $(2 \mathrm{n}=10)$, $P$ tetraphylla $(2 \mathrm{n}=10)$, Trillium kamtschaticum $(2 \mathrm{n}=10), T$. Tschonoskii $(2 \mathrm{n}=20), T$. Smallii $(2 \mathrm{n}=20)$ and their varieties and forms, cover a very large area from the arctic to the southern part of Japan (as far as Kyushu). But the southern limit of the abundant occurrence of them is located in the restricted distribution area of $K$. japonica, certain species, e.g., T. kamtschaticum, being limited up to the middle portion of this area.

This fact is significant enough to support the 4-genomatic or balanced allo-octoploid origin of the present plant (cf. NAVASHIN 1929). It is inferred then that in a geological epoch the constant allo-octoploid $K$. japonica appeared through certain steps of the hybridisations between the lower polyploid plants of the Parideae (cf. HAGA 1934, 1937 a), the restricted present-day distribution having been caused as in the case of Fritillaria (MATsuURA 1935) by the characteristic biological unadoptability which may result in the abnormal meiosis and under-growth of the plant body when transplanted in different climatic regions such as in Sapporo.

\section{Summary}

1. From the morphology and behavior of the chromosomes and from the geographical view point, the gametic complement $4(\mathrm{~A}+\mathrm{B}+\mathrm{C}+\mathrm{D}+\mathrm{E})=20$ chromosomes of Kinugasa japonica was suggested to be composed of 4 different genoms.

2. Meiotic chromosome irregularities, fragmentation-fusion, non-pairing, tertiary splitting and regression of the first division were observed.

Particular thanks are due to Professor H. MATsuURA who has kindly taken the photomicrographs, giving very helpful suggestions and criticisms.

1) According to many local lists, especially those by MiYABE and KUdo (1932) and by TATEWAKI and Sutô (1935). 


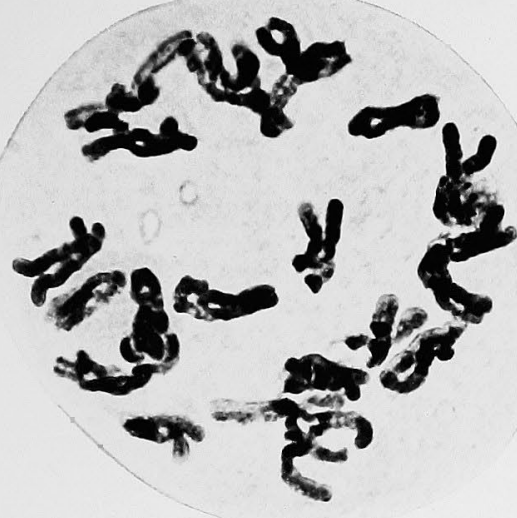

1

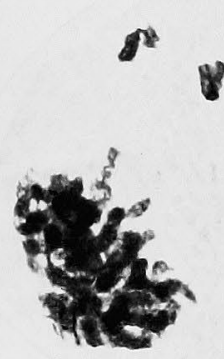

-

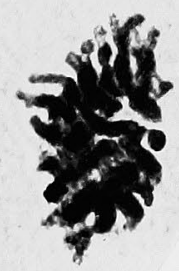

3

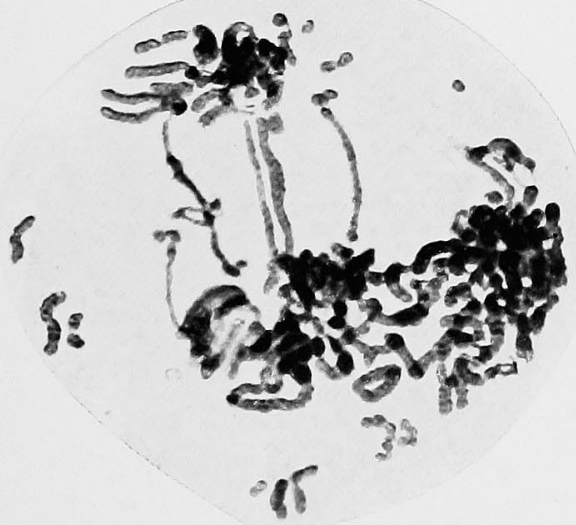

5

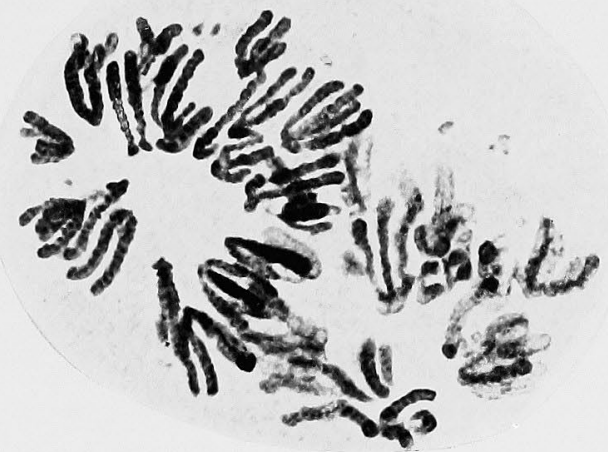

2

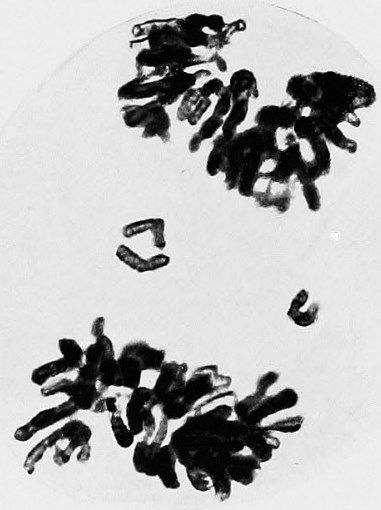

4

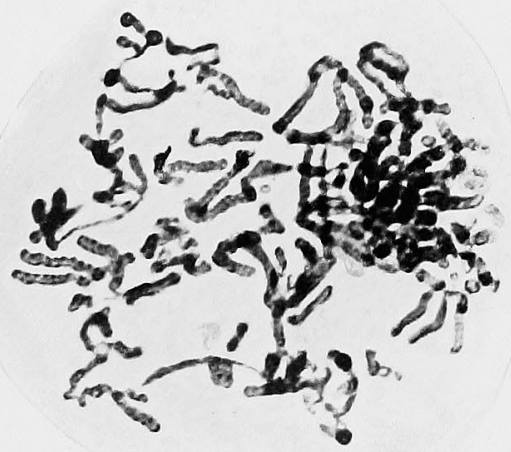

6

H. Matsuura photo.

Haga : Chromosome Complement of Kinugasa japonica with Special Reference to Its Origin and Behavior 


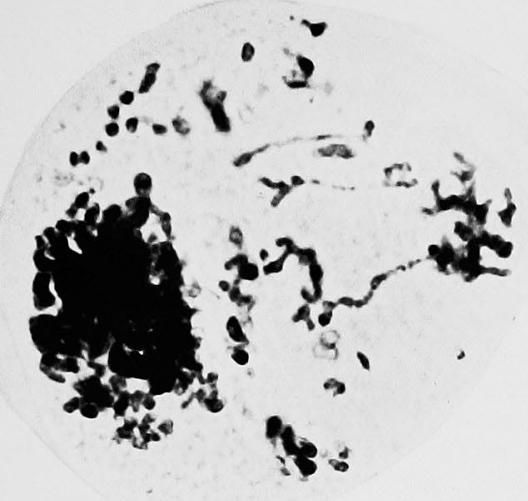

7
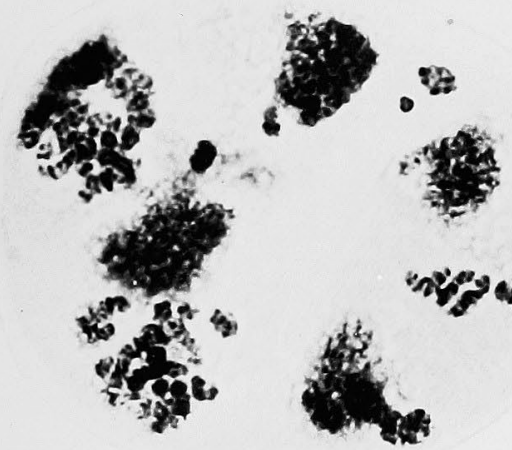

9

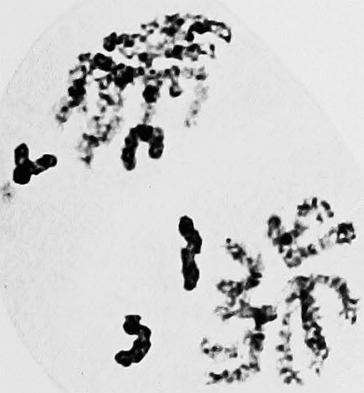

11
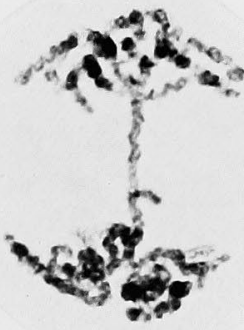

12

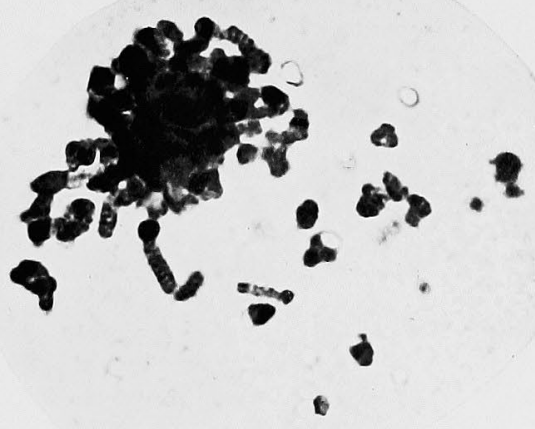

8

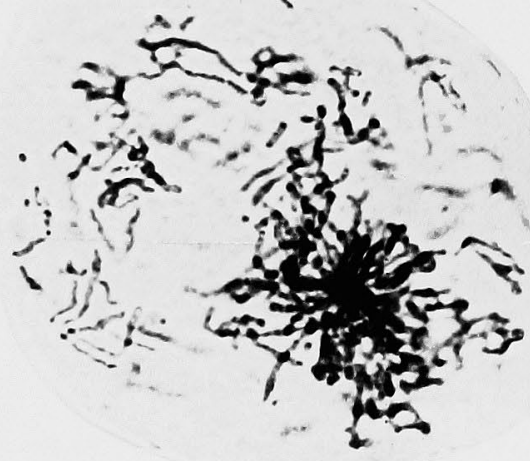

10

H. Matsuura photc.

Haga: Chromosome Complement of Kinugasa japonica with Special Reference to Its Origin and Behavior 


\section{Literature Cited}

Haga, T. 1934. The comparative morphology of the chromosome complement in the tribe Parideae. Journ. Fac. Sci. Hokkaido Imp. Univ. Ser. V. 3: 1-32.

- 1937a. Genom and polyploidy in the genus Trillium. I. Chromosome affinity between the genoms. Japan. Journ. Gen. 13. (in the press).

- 1937b. Karyotypic polymorphism in Paris hexaphylla Cham., with special reference to its origin and to the meiotic chromosome behavior. Cytologia Fujii Jub. Vol. (in the press).

Matsuura, H. 1935. On karyo-ecotypes of Fritillaria camtschatcensis (L.) KERGAWLER. Journ. Fac. Sci. Hokkaido Imp. Univ. Ser. V. 3: 219-232.

- and Haga, T. 1937. Chromosome studies on Trillium kamtschaticum. VI. The effects of X-radiation upon the meiotic chromosomes. (Unpublished).

Miyabe, K. and Kudo, X. 1932. Flora of Hokkaido and Saghalien. III. Journ. Fac. Agr. Hokkaido Imp. Univ. $26: 279-387$.

Navashin, M. 1929. Studies on polyploidy. I. Cytological investigations on triploidy in Crepis. Univ. Calif. Fubl. Agr. Sei. $2: 377-400$.

Nebel, B. R. 1936. Chromosome structure. X. An X-ray experiment. Genetics 21: 605-614.

Takagi, F. 1928. The influence of higher temperature on the reduction division of the pollen mother cells of Lychnis Sieboldii, van Houtte. Sci. Rep. Tohoku Imp. Univ. Ser. IV. 3: 461-466.

Tatewaki, M. and Sutô, T. 1935. On the new genus Kinugasa. Transact. Sapporo Nat. Hist. Soc. $14: 34-37$.

\section{Explanation of Plates}

Figs. 1-13 (Pls. 12 and 13). Meiotic divisions in PMCs. Figs. 1-10. Kinagasa japonica. Figs. 11-13. Trillium kamtschaticum. Acetocarmine preparation. $\times 570$.

Plate 12

Fig. 1. First metaphase clearly showing the pairing in $4\left(\mathrm{~A}_{I I}+\mathrm{B}_{I I}+\mathrm{C}_{I I}+\mathrm{D}_{I I}+\mathrm{E}_{11}\right)$ $=20$ bivalents.

Fig. 2. First anaphase dividing into 2 groups of $4(\mathrm{~A}+\mathrm{B}+\mathrm{C}+\mathrm{D}+\mathrm{E})=20$ half bivalents.

Fig. 3. Lagged division of 2 E-univalents.

Fig. 4. The same as photo 3 , but a slightly earlier stage.

Fig. 5. Irregular first division showing fragmentation, fusion, desynapsis etc. Spindle polarity is effected. Note the tertiary splitting of the fragment oriented horizontally at the middle portion of the second bridge from the left.

Fig. 6. The same as photo 5 ; note the traceable changes in chromosome structure.

\section{Plate 13}

Fig. 7. The same as photo 5-6, showing more severe fragmentation and more severely effected spindle.

Fig. 8. The same as photos 5-6, showing the disappearance of spindle polarity.

Fig. 9. A pollen-tetrad stage resulting from the irregularities shown in photos 3-8.

Fig. 10. Tertiary splitting of the whole chromosomes and their fragments, spindle polarity being nullified.

Fig.11. Lagged division of 2 E-univalents, corresponding to photos 3-4.

Fig.12. Fragmentation and fusion.

Fig. 13. Extreme fragmentation comparable with photos 5-8. 